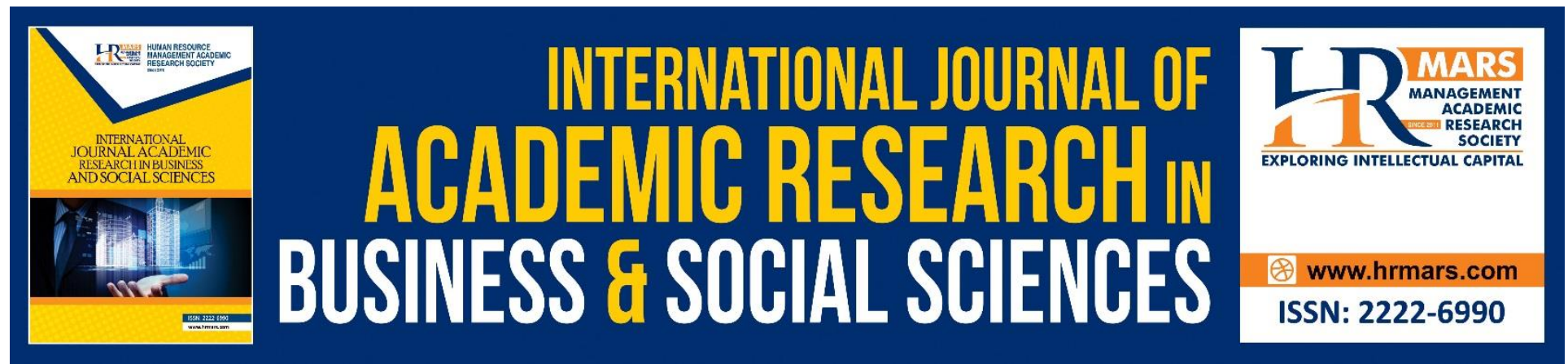

\title{
Organisational Man: Secret Weapon for Increasing Organisational Commitment in The Hotel Industry
}

Siti Aishah Edros, Hashim Fadzil Ariffin, Mohamad Abdullah Hemdi

To Link this Article: http://dx.doi.org/10.6007/IJARBSS/v11-i10/11511 DOI:10.6007/IJARBSS/v11-i10/11511

Received: 08 August 2021, Revised: 01 September 2021, Accepted: 28 September 2021

Published Online: 19 October 2021

In-Text Citation: (Edros et al., 2021)

To Cite this Article: Edros, S. A., Ariffin, H. F., \& Hemdi, M. A. (2021). Organisational Man: Secret Weapon for Increasing Organisational Commitment in The Hotel Industry. International Journal of Academic Research in Business and Social Sciences, 11(10), $1294-1306$.

\section{Copyright: (c) 2021 The Author(s)}

Published by Human Resource Management Academic Research Society (www.hrmars.com)

This article is published under the Creative Commons Attribution (CC BY 4.0) license. Anyone may reproduce, distribute, translate and create derivative works of this article (for both commercial and non-commercial purposes), subject to full attribution to the original publication and authors. The full terms of this license may be seen

at: http://creativecommons.org/licences/by/4.0/legalcode

Vol. 11, No. 10, 2021, Pg. $1294-1306$

http://hrmars.com/index.php/pages/detail/IJARBSS

JOURNAL HOMEPAGE

Full Terms \& Conditions of access and use can be found at http://hrmars.com/index.php/pages/detail/publication-ethics 


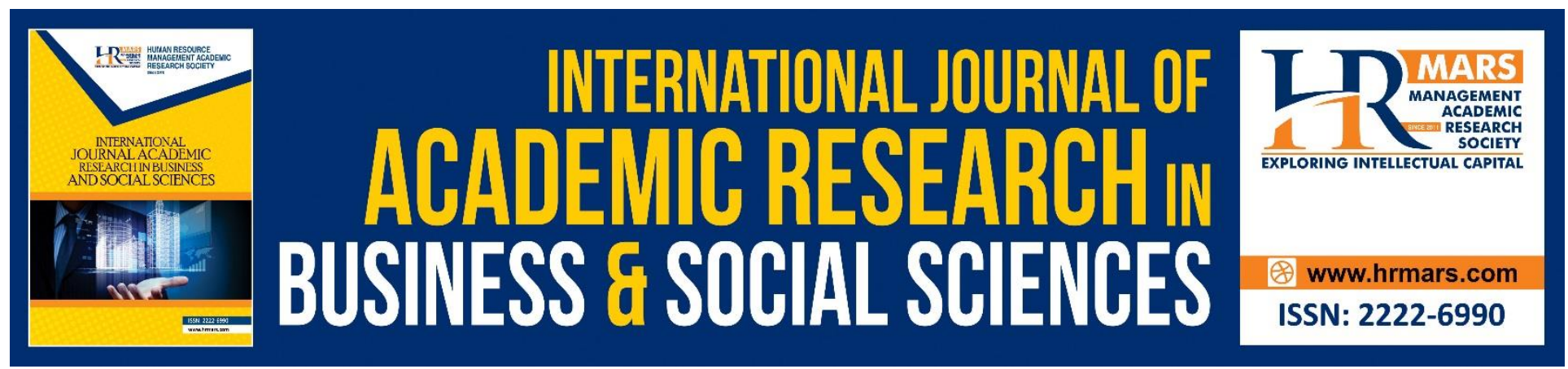

\title{
Organisational Man: Secret Weapon for Increasing Organisational Commitment in The Hotel Industry
}

\author{
Siti Aishah Edros ${ }^{1}$, Hashim Fadzil Ariffin², Mohamad Abdullah \\ $\mathrm{Hemdi}^{3}$ \\ 'Department of Polytechnic Education and Community College, Putrajaya, Malaysia, ${ }^{2}$ Universiti \\ Teknologi MARA, Pulau Pinang Branch, Permatang Pauh Campus, Pulau Pinang Malaysia, \\ ${ }^{3}$ Universiti Teknologi MARA, Kedah Branch, Sungai Petani Campus, Kedah, Malaysia.
}

\begin{abstract}
The main objective of this paper is to describe organisational commitment displayed among hotel employees with regard to the different ways its level can be boosted. This work specifies a critical secret weapon that organisations should be cognisant of to ensure their employees' commitment towards their job is retained and loyalty to the entity is secured. In particular, the connection perceived between organisational commitment, leadership style, and the social exchange theory plays a vital and significant role. The methodology implemented includes identifying resources for locating pertinent articles, whereby literature reviews are sought as the secondary data. Here, the correct keywords are identified and thus incorporated during the search process, while the eligibility of information is ascertained accordingly. In this study, the supporting materials deemed necessary and of relevance are obtained by using electronic databases available at the library databases of Universiti Teknologi MARA, which include Scopus, SAGE, Academia, and ResearchGate. The concluding comments detail the authors' aspiration and beneficial elements attainable due to this work to its readers.
\end{abstract}

Keywords: Organisational Commitment, Leadership, Social Exchange Theory

\section{Introduction}

Over the past 20 years, various challenges have been identified in doing business to achieve a competitive advantage (Abd Halim \& Ali Alsheikh, 2017). In the United States of America (USA), the hospitality industry is highly in demand and contributory to its economy and society. The accommodation-based industry and services encompass hotels (e.g. resort hotels, budget hotels, and apartment hotels), chalets and rest houses, guest houses, hostels, bed and breakfast, and camping grounds (Department of Survey and Mapping, 2018). Accordingly, the tourism and hospitality industries are some of the sectors that can also contribute to the Sustainable Development Goals (SDGs) towards improving financial and societal growth (Jones \& Comfort, 2019). 
INTERNATIONAL JOURNAL OF ACADEMIC RESEARCH IN BUSINESS AND SOCIAL SCIENCES Vol. 11, No. 10, 2021, E-ISSN: 2222-6990 @ 2021 HRMARS

The above statement is supported by the World Tourism Organisation and United Nations Global Compact Network Spain (2016), whereby the tourism industry is underlined as the industry with the most potential towards enhancing the economy and contributing to SDG achievements. In 2018, Malaysia received a total of 25,832,354 international tourists (TOURISM MALAYSIA, 2018). To the author's knowledge, however, previous studies have revealed that the hotel industry is associated with an increasingly higher turnover rate regardless of the incremental tourist receipt numbers. This is further reflected in the major foreign exchange earnings in 2018 listed based on Figure 1.0 below.

For example, one of the studies has revealed that the level of organisational commitment among hoteliers is low (Davis, 2018). This supports another observation that the number of hotel employees quitting their job within two years of the maximum period of working has become an issue (El-Houshy, 2018). Similarly, works from other researchers have reached a consensus regarding the issue of hotel industry turnover in the sector over the past decades (Abo-murad, 2019; Abo-Murad \& AL-Khrabsheh, 2019; Tan et al., 2019) Figure 2.0 depicts information generated by the National Restaurant Association (2019), proving the incremental turnover rate in the restaurant and accommodation sector from the year 2010 until 2018.

Such an issue is also prevalent in Malaysia, as deduced by a group of researchers in which the level of organisational commitment among hotel employees is steadily reducing (Zainuddin et al., 2019). To the best of the author's knowledge, employees denote the backbone of the industry and thus call for highly committed individuals. To this end, the number of employees engaged in any organisation can be retained by introducing effectual leadership championed by effective leaders, either through managerial or supervisory positions. However, the lack of studies investigating this topic in the context of hotel industry employees in Malaysia has been identified accordingly (Saeed et al., 2018).

As such, issues associated with employee commitment towards their organisation have driven the authors to reveal the secret weapons or applicable strategies in increasing the level of organisational commitment, particularly in the context of the hotel industry.

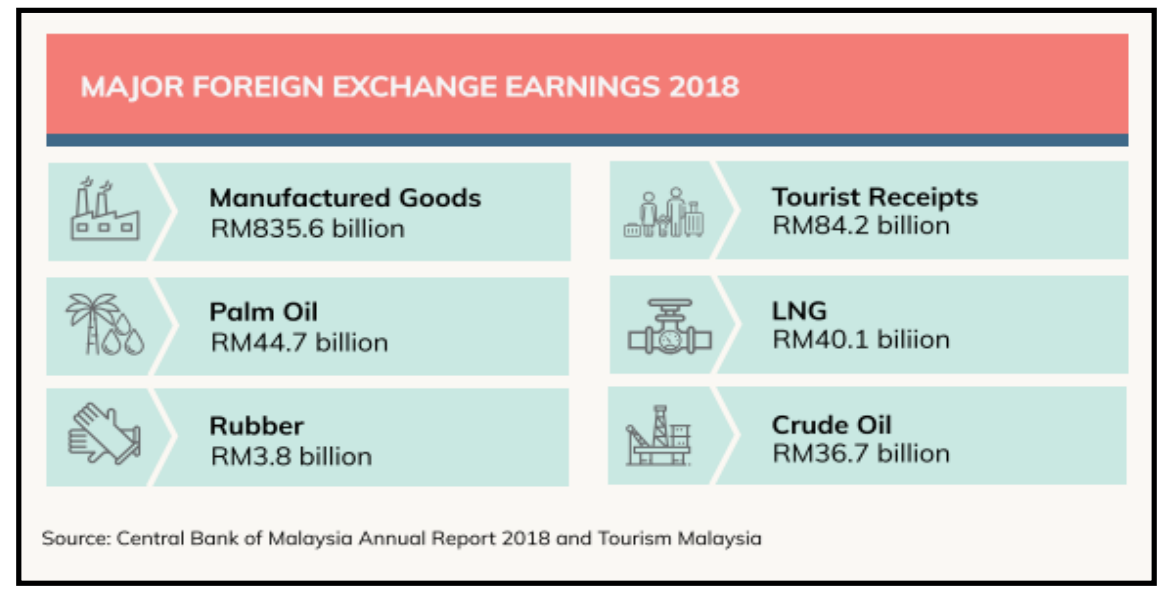


INTERNATIONAL JOURNAL OF ACADEMIC RESEARCH IN BUSINESS AND SOCIAL SCIENCES Vol. 11, No. 10, 2021, E-ISSN: 2222-6990 @ 2021 HRMARS

Figure 1: Major foreign exchange earnings in 2018 (Source: Tourism Malaysia,2018)

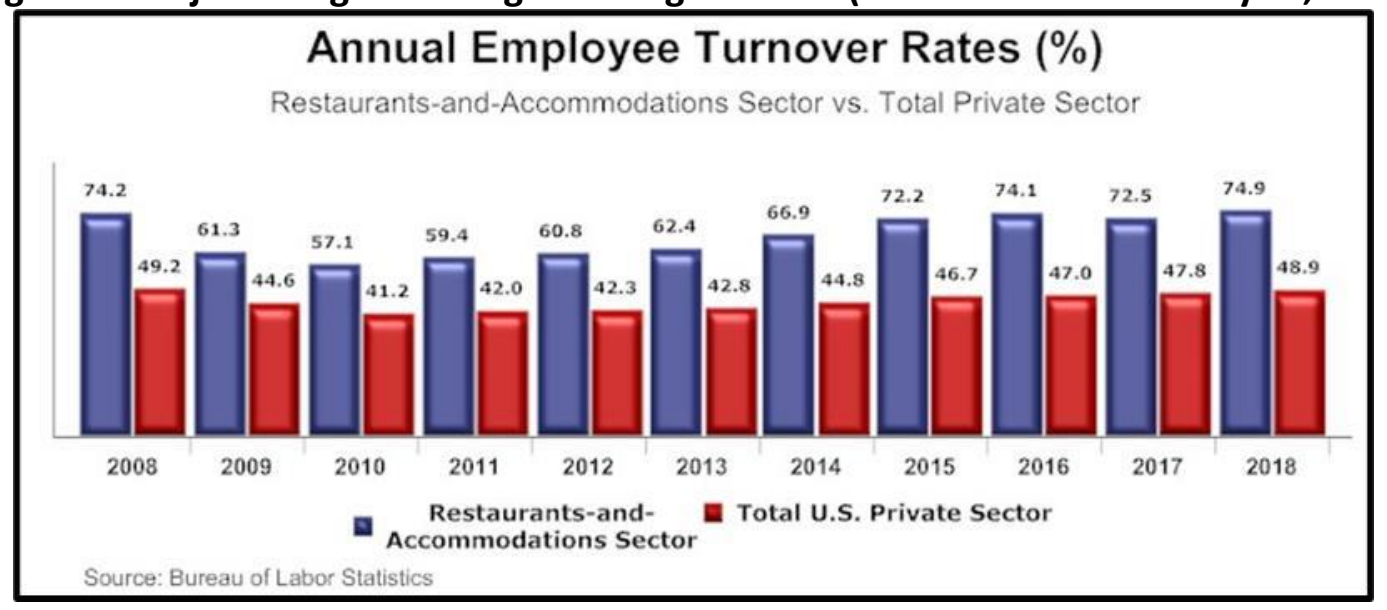

Figure 2.0: Turnover rate (Adopted from Media \& Press NRA, 2019)

\section{Organisational Commitment}

To date, an increasing volume of research regarding the effect of organisational commitment on employee and organisational outcomes has been observed. Accordingly, it is a notable area of interest for a considerable period, ranging from the early 1960s by Becker (1960) until current times (Yeh, 2019). However, a literature review has indicated that its introduction is not dated back to the 1960s; instead, the 1950s resulted in Whyte's (1956) publication entitled "Organisation Man", which already gained the attention of researchers (Pelenk, 2020). The fact that organisational commitment has been investigated since the 1950s is undoubtedly proof that retaining employees and ensuring their organisational commitment are important and pose a significant effect on organisations themselves. The most cited research related to such works has revealed that organisational commitment contains three aspects, namely affective commitment, continuance commitment, and normative commitment. These elements should be exhibited by leaders and organisations to sustain the organisational commitment among their employees (Meyer \& Allen, 1984).

Furthermore, the construct of organisational commitment is fundamentally comprised of the emotional state of mind, loyalty towards an organisation, and the respect of the leader and organisation itself. This statement is supported by prior empirical research, which has underlined the positive and significant relationship between organisational commitment, servant leadership, and organisational support in the foodservice industry (Piong, 2016).

Henceforth, the importance of employees as the "Organisational Man" is loudly amplified due to the fact that minimising the turnover rate in the hotel industry and boosting job performance levels are possible as a result of an increasing sense of organisational commitment. This statement has been analysed extensively by authors worldwide in ascertaining the benefits of sustaining organisational commitment levels among employees, which is also applicable in other industries beyond the hotel industry. In particular, Becker's side-bet theory has been correlated to organisational commitment, whereby employee's perception of the time and money invested into their organisation should be repaid or rewarded, and vice versa. This ensures their sense of responsibility and love towards the entity, which occurs if they are extended a treatment similar to what they offer (Zhao, 2019). 
INTERNATIONAL JOURNAL OF ACADEMIC RESEARCH IN BUSINESS AND SOCIAL SCIENCES Vol. 11, No. 10, 2021, E-ISSN: 2222-6990 @ 2021 HRMARS

It is worth noting that the departure of committed employees from an organisation is financially costly in the context of their financial stature and image in the perspective of their rivals. For example, a study undertaken in Spain has critically reviewed the gravity of organisational functions and future direction, thus highlighting the ultimate mission of ensuring employee commitment(Keskes, 2014). Retaining a sustainable level of commitment for this population necessitates the abovementioned criteria of organisation commitment, which is especially true for the hospitality industry due to its demanding peak period or around-the-clock operational hours (Bhat, 2017).

Moreover, the higher amount of tourists coming in should be correlated with the number of employees engaged in the hotel and tourism industry. Regardless of these elements, the industry must ensure that its employees' commitment towards their organisations is in the right position, which is necessary to sustain its role as a major contributor to the national economic revenue. Literature reviews on the topic call for organisations to take care of their employees and retain their organisational commitment. This is further highlighted in how the three commitment criteria emphasise the significance of organisational commitment among employees in any organisation (Meyer et al., 1993).

In general, organisations must heed the three components of organisational commitment, namely affective commitment, continuance commitment, and normative commitment. Affective commitment, for example, is known as desire while continuance commitment is the need for life, whereas normative commitment is classified as one's obligation towards an organisation (Tan et al., 2019). By answering to all three commitment types, employee work-life balance is secured and the turnover rate can be reduced, especially in the hotel industry (Farrell, 2015). Organisational commitment is undeniably critical as per its significant outcomes should organisations realise the importance of each dimension accordingly (Domínguez-Falcón et al., 2016). Besides, some studies have indicated that this element will produce more productive employees and increase the sense of organisational citizenship behaviour among these individuals (Edros et al., 2020; Grego-planer, 2019).

\section{Leadership Styles}

In general, various leadership styles are applied in the business and management field worldwide in which leadership is specifically positioned as a secret weapon or strategy to increase organisational commitment. This is supported by other correlated studies depicting leadership styles that can increase one's commitment towards organisations, especially in the hotel industry, and result in employee retainment (Daskin, 2016). The importance of leadership to increase commitment spans various goals, including minimising the turnover rate, influencing team members to achieve organisational goals, and driving employee motivation as an operational component in the entity; this population needs the best leadership (Saeed et al., 2018; Yahaya \& Ebrahim, 2016).

Hotel-based leadership studies in Malaysia have detailed different leadership types, such as transformational, transactional, laissez-faire, and servant leadership. A systematic literature review, in particular, has revealed that studying these styles necessitates researchers to prove that leadership is significant and requires serious managerial attention, undoubtedly enhancing 
INTERNATIONAL JOURNAL OF ACADEMIC RESEARCH IN BUSINESS AND SOCIAL SCIENCES Vol. 11, No. 10, 2021, E-ISSN: 2222-6990 @ 2021 HRMARS

the level of organisational commitment among employees (Yahaya \& Ebrahim, 2016). A good employee comes from a great leader; this has been proposed by Dr. (Al-Ababneh, 2013) following their study in the context of the Jordanian hotel industry. Here, leadership is the backbone of a great hotel operation and produces the best employees.

Back in the 1980s, leadership is conceptually known using several themes, such as "do as the leader wishes", influence, traits, and transformation. In the $21^{\text {st }}$ century, however, scholars have agreed that it does not have one specific meaning; contrarily, it holds different meanings for different people (Northouse, 2012) as shown in Figure 1.0 below. Theoretically, leadership can denote any themes used previously for different people as per the type employed by their leaders. For example, leaders implementing a positive style will depict employees in a similar manner, while those with inconsideration for their employees are attributable to a negative leadership style. Prior discourses have indicated that minimal research is available on leadership and organisational commitment despite the prevalent and continuous issues seen of the topic, especially in the context of the Malaysian hotel industry (Lo et al., 2010).

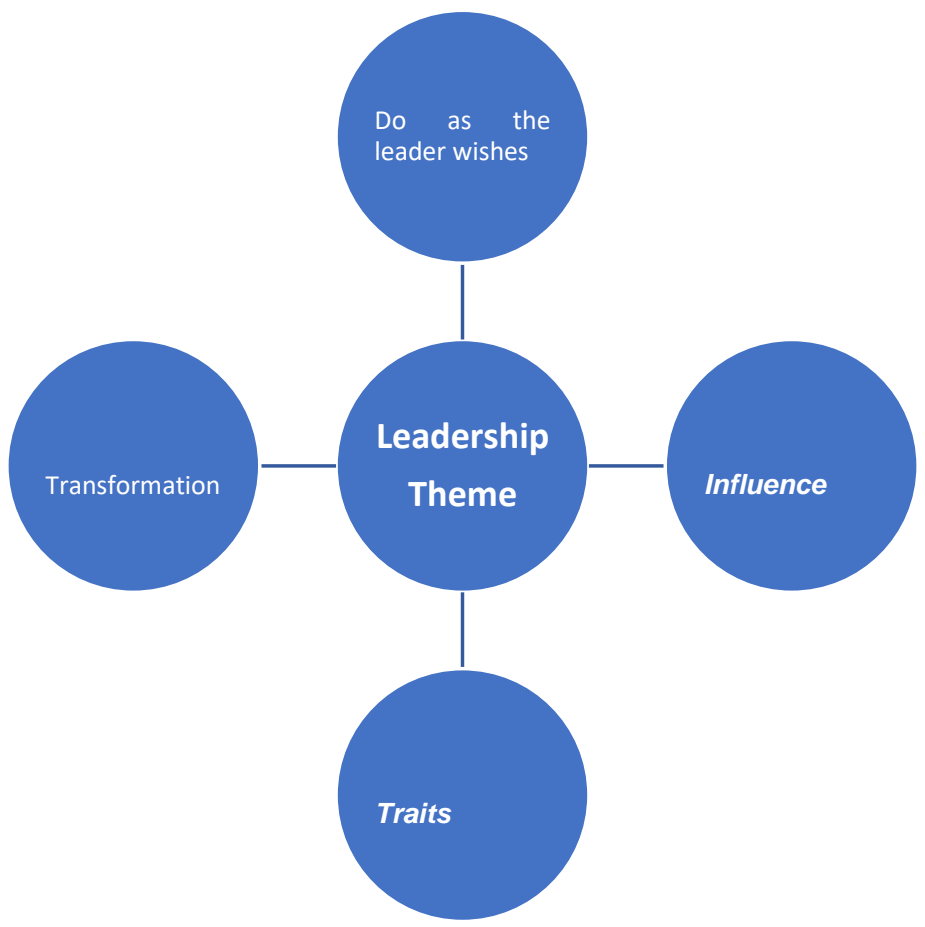

Figure 3.0: Leadership themes (Northouse, 2012)

Figure 3.0 above depicts the four themes of leadership, which can be delineated in line with the evolution of leadership. The progression commenced as early and the 1900 s in which earlier definitions for the word were detailed in a conference in 1927. Leadership, for example, describes the capability of a leader to impress others, being a leader, and encouraging loyalty, respect, and teamwork for their followers. After a decade, four themes have been identified by scholars and detailed accordingly in Northouse's book published in 2012 as follows:

- Do as the leader wishes. 
INTERNATIONAL JOURNAL OF ACADEMIC RESEARCH IN BUSINESS AND SOCIAL SCIENCES

Vol. 11, No. 10, 2021, E-ISSN: 2222-6990 @ 2021 HRMARS

This theme has its own pros and cons. In the $21^{\text {st }}$ century, Generation-Z or alpha individuals are required to undertake two-way communication with their leader. If they have any issues with their supervisors or leader, youngsters of this generation will quit within six months (Richardson, 2010).

- Influence.

A leader must have a sense of influence on their followers from every angle possible, specifically a good side as opposed to the bad side of said individual.

- Traits.

This theme is crucial as leaders require certain traits to lead their followers and being role models or not. Discussions of the theme in prior servant leadership style-focused works have underlined the need for leaders to have good and quality traits as considered by both leaders and followers (Krog \& Govender, 2015).

- Transformation.

As a leader, being inspired by their followers is a crucial process of being a great one (Kindy et al., 2016) and necessary in being a good leader.

On top of this, prominent leadership scholars such as Heifetz, Burns, and Greenleaf have also made unique contributions to the current understanding of ethical leadership. The theme commonly highlighted by these authors is an ethos of caring, specifically paying attention to followers' needs and being cognisant of leader-follower relationships and their importance (Northouse, 2012).

\section{Social Exchange Theory}

The social exchange theory is a global and driven approach for utilising social interaction in the social science field in delineating the level of exchange occurring between two parties. Otherwise termed as reciprocity between both parties, this theory has been extensively discussed by Homan and Blau in the 19580s (Cook, 2015). It reveals the relationship between individuals, namely employees and organisations, and suggests that the former may emerge as good or bad employees in the future as a result (Ma \& Qu, 2011). When viewed as an indicator of contribution for both parties, studies have revealed that an excellent correlation will be seen following the occurrence of interdependence between them (Cropanzano \& Mitchell, 2005). Thus, the theory is intimately linked with the cost and benefits of exchange in which one party assumes to receive a reward based on the level of contribution that they offer.

Beyond its social implication, the social exchange theory further reflects the economic exchange that occurs, whereby the economic background of an individual or organisation will improve following the fulfilment of their social exchange (Cropanzano et al., 2017). According to researchers, this theory is critical in the 20th century and in the era of globalisation, requiring extensive attention from people of all backgrounds to ensure excellent organisations and economic status (Chernyak-Hai \& Rabenu, 2018). To the best of the author's knowledge, it should be applied extensively in entities to ensure employee satisfaction and organisational strength, thereby becoming primed for leading their economic aspects in the future. 
INTERNATIONAL JOURNAL OF ACADEMIC RESEARCH IN BUSINESS AND SOCIAL SCIENCES Vol. 11, No. 10, 2021, E-ISSN: 2222-6990 @ 2021 HRMARS

This theory is heavily highlighted in the current work due to its benefits to different parties. For example, a Surabaya-based work has indicated that attitude and behaviour are closely related to the level of exchange seen between leaders and employees (Anang Subardjo \& Harjanti, 2019). Henceforth, the social exchange theory primarily underpins discussions on organisational behaviour, organisational commitment, justice, trust, perceived organisational support, employee engagement. It is also linked to certain topics on organisational behaviour related to two parties, namely employee and leader-related and employee and organisation-related behaviours (Aktar \& Pangil, 2017; Almaaitah et al., 2017; Cropanzano et al., 2017).

Besides, prior works detailing leadership and organisational commitment in the restaurant sector have proven the theory's status as the underlying element promoting reduced employee turnover rate as they feel appreciated by their leader and organisation (Jang \& Kandampully, 2018a). This situation is born following the fulfilment of balance and repayment, rendering reciprocity a practiced strategy in such an organisation (Blau, 1989). Therefore, the social exchange theory remains relevant and is a dominating theory still in current times due to the proven benefits of exchange from time to time.

\section{The Relationship between Organisational Commitment and Leadership Style}

The above discussion on leadership and organisational commitment as the underpinning constructs of the social exchange theory suggests the presence of evidence proving the relationship between leadership styles and organisational commitment. The review performed has revealed several prior works depicting the significance of such a relationship. For example, a study analysing 20 hotels in India has highlighted the importance of leadership style towards boosting employee organisational commitment (Bhat, 2017). The work only focused on frontline employees, however, rendering other operational employees unrepresented in the current literature despite earlier scholars calling for them to be investigated. These operational employees include kitchen and housekeeping employees, among others.

Alternatively, a study undertaken in Madda Walabu University, Bale Robe, Ethiopia has discussed the effectiveness of good leadership styles and their role to boost the organisational commitment among the employees. Furthermore, such elements will benefit organisations and employees in terms of reduced turnover rate, increased level of effectiveness, and increased job performance among the latter population (Ozdemir, 2017). Meanwhile, the effect of leadership styles and organisational commitment in the context of American restaurants has been investigated and proven the significant outcome of such correlation (Jang \& Kandampully, 2018).

A systematic literature review detailing the relationship between leadership style and organisational commitment has further indicated their role as excellent parameters in measuring their respective significance, specifically in the hotel industry field for future reference (Yahaya \& Ebrahim, 2016). Supporting evidence has revealed that the intimate link between both elements will boost employee engagement and improve job satisfaction (Naiemaha et al., 2019). Thus, this paper discusses the not-so-secret weapon or key of organisational effectiveness, namely leadership styles, which is further bolstered by the social exchange theory in ensuring an improved organisational commitment. 


\section{Conceptual Framework Proposed}

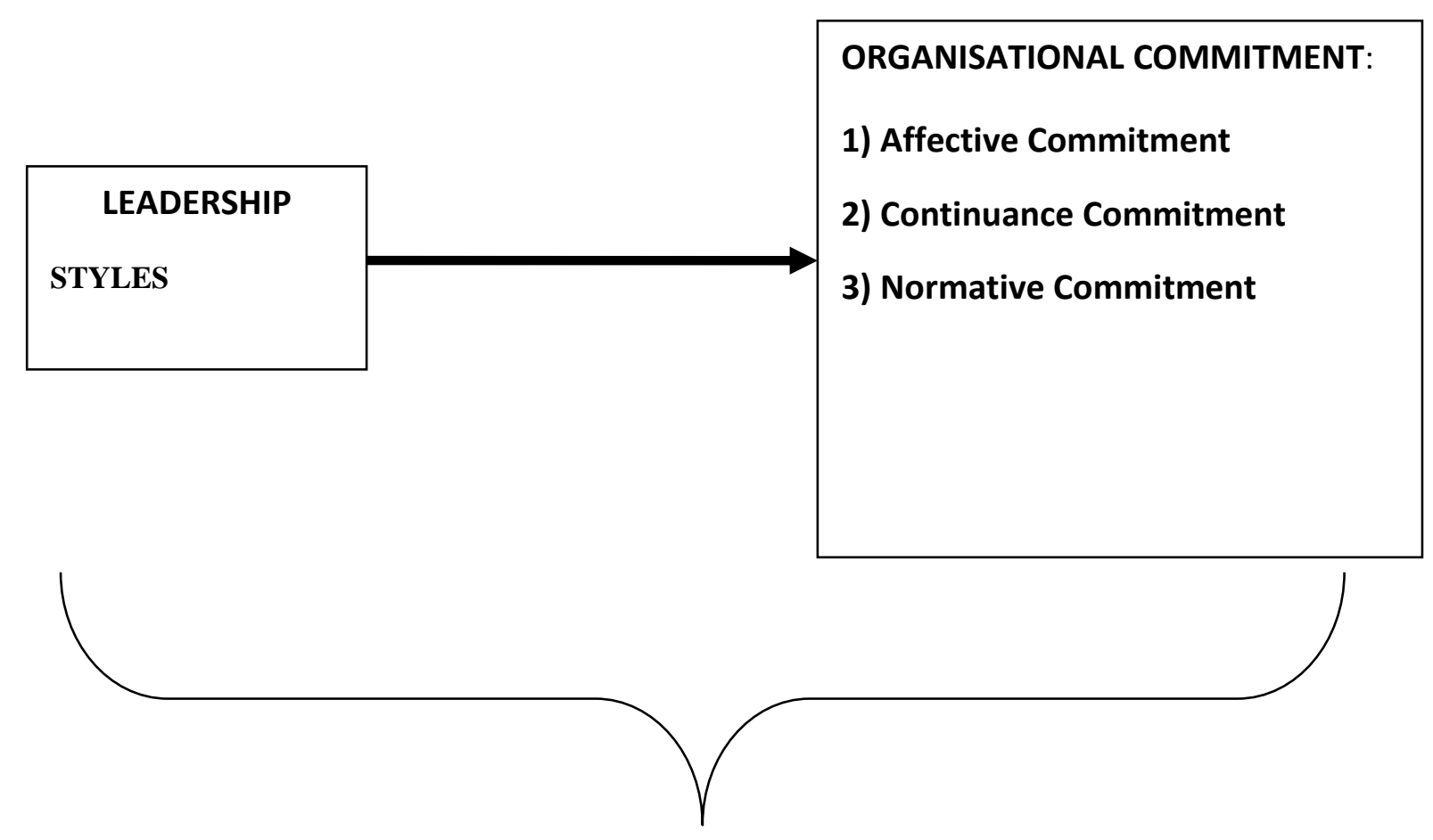

SOCIAL EXCHANGE THEORY

Based on the discussion included in this paper, the above conceptual framework is proposed accordingly. The dependent variable suggested is denoted by organisational commitment, which encompasses three dimensions as the focal highlight for readers, while leadership style serves as the predictor for the framework. Accordingly, this framework underlines the significance of the social exchange theory as the theoretical underpinning of the current work.

\section{Conclusion}

The current paper aimed to investigate the relationship between leadership style and organisational commitment, specifically in the context of the hotel industry. The former element was deemed as the proposed predictor due to the staggering turnover rate recorded among hotel employees. Accordingly, the significance of the leadership themes, the history of leadership, and other secret weapons applicable to increase the organisational commitment among hotel employees was delineated via the implementation of the social exchange theory.

Furthermore, a proposed conceptual framework was depicted in detail for future empirical research following the beneficial implications attached to the topic towards the relevant organisations and industry. The younger generations, in particular, have been linked with worsening perception of the hotel industry due to many reasons, including ineffective leadership, among others (Richardson, 2010). This calls for future works implementing the proposed framework to generate an empirical outcome or referencing the content included in this work for leaderships to improve their knowledge and skills for the purpose of enhancing their employees' organisational commitment. Undoubtedly, the combination of quality leadership and social exchange theory implementation will aid organisations in minimising employee turnover rates and improving their employees' loyalty. In the long run, 
the ability to retain these employees will allow these entities to reduce the financial costs associated with training new staff.

\section{Acknowledgment}

I would like to specifically acknowledge my both supervisors, Assoc. Prof. Dr. Hashim Fadzil Ariffin and Prof. Dr. Mohamad Abdullah Hemdi which are Professor of the Faculty of Hotel and Tourism Management, UiTM Malaysia, for their unceasing help in conducting this study. All authors have been delegated to their own tasks and extensively contributed to writing and analysing the information necessary for this article.

\section{Corresponding Author}

Assoc. Prof. Dr. Hashim Fadzil Ariffin

Faculty of Hotel and Tourism, Universiti Teknologi MARA, Penang Branch Campus, Malaysia. Email: hashim@uitm.edu.my

\section{References}

Abd Halim, M. S., \& Alsheikh, A. G. A. (2017). A Study on the Relationship between Organizational Culture, Leadership Style, Organizational Commitment and Organizational Citizenship Behaviour , Intrinsic Motivation as Mediating with Reference to Employees Working in Jordanian Luxury Class Hotel. World Applied Sciences Journal, 35(December), 119-126. https://doi.org/10.5829/idosi/wasj.seiht.2017.119.126.

Abo-murad, M. (2019). Turnover Culture and Crisis Management : 18(2), 1-14.

Abo-Murad, M., \& AL-Khrabsheh, A. (2019). Turnover culture and crisis management: Insights from Malaysian hotel industry. Academy of Strategic Management Journal, 18(2), 1-14.

Aktar, A., \& Pangil, F. (2017). The Relationship between Employee Engagement, HRM practices and Perceived Organizational Support: Evidence from Banking Employees. International Journal of Human Resource Studies, 7(3), 1. https://doi.org/10.5296/ijhrs.v7i3.11353

Al-Ababneh, M. (2013). Leadership \nStyle of Managers in Five-Star Hotels and its Relationship with\nEmployee's Job Satisfaction. International|nJournal of Management \&amp; Business Studies, 9519, 93-98.

Almaaitah, M. F., Harada, Y., Sakdan, M. F., \& Almaaitah, A. M. (2017). Integrating Herzberg and Social Exchange Theories to Underpinned Human Resource Practices, Leadership Style and Employee Retention in Health Sector. World Journal of Business and Management, 3(1), 16. https://doi.org/10.5296/wjbm.v3i1.10880

Subardjo, A. S., \& Harjanti, W. (2019). The Impact of Social Exchange Theory Implementation Over Organizational Attitude and Behavior. International Journal of Scientific and Research Publications (IJSRP), 9(7), p9159. https://doi.org/10.29322/ijsrp.9.07.2019.p9159

Bhat, R. K. (2017). Job Satisfaction \& Organizational Commitment in the Hospitality Industry: Vol. Id. No. 11 (Issue JOSEPH SCHOOL OF BUSINESS STUDIES).

Blau P.M. (1989). Exchange and power in social life. Exchange and Power in Social Life, 1-352. https://doi.org/10.4324/9780203792643

Chernyak-Hai, L., \& Rabenu, E. (2018). The New Era Workplace Relationships: Is Social Exchange Theory Still Relevant? Industrial and Organizational Psychology, 11(3), 456481. https://doi.org/10.1017/iop.2018.5

Cook, K. S. (2015). Exchange: Social. In International Encyclopedia of the Social \& Behavioral 
Sciences: Second Edition (Second Edi, Vol. 8). Elsevier. https://doi.org/10.1016/B978-008-097086-8.32056-6

Cropanzano, R., Anthony, E. L., Daniels, S. R., \& Hall, A. V. (2017). Social exchange theory: A critical review with theoretical remedies. Academy of Management Annals, 11(1), 479516. https://doi.org/10.5465/annals.2015.0099

Cropanzano, R., \& Mitchell, M. S. (2005). Social exchange theory: An Interdisciplinary review. Journal of Management, 31(6), 874-900. https://doi.org/10.1177/0149206305279602

Daskin, M. (2016). The Role of Leadership Style on Frontline Employees ' Perceived Ethical Climate, Polychronicity and Service Recovery Performance: An Evaluation from Customer Service Development Perspective Liderlik Stillerinin Müşterilerle Yüz Yüze İrtibatlı Çalışanlar. Journal of Entrepreneurship and Innovation Management, 5(2), 125158.

Davis, O. (2018). Strategies for Low Employee Turnover in the Hotel Industry .Walden University.

Department of Survey and Mapping. (2018). Department of Statistics Malaysia. Department of Statistics Malaysia, Official Portal, February. https://doi.org/10.1002/bbb.1450

Domínguez-Falcón, C., Martín-Santana, J. D., \& De Saá-Pérez, P. (2016). Human resources management and performance in the hotel industry: The role of the commitment and satisfaction of managers versus supervisors. International Journal of Contemporary Hospitality Management, 28(3), 490-515. https://doi.org/10.1108/IJCHM-08-20140386

Edros, S. A., Samsudin, S. A., \& Yusof, W. M. R. W. (2020). Beyond the Call of Duty: Determinants and Consequences of Organizational Citizenship Behaviour on going 21st Century. International Journal of Academic Research in Business and Social Sciences, 10(7), 638-649. https://doi.org/10.6007/IJARBSS/v10-i7/7595

El-Houshy, S. (2018). Hospitality Students' Perceptions towards Working in Hotels: a case study of the faculty of tourism and hotels in Alexandria University. 2002, 800-819. http://arxiv.org/abs/1807.09660

Farrell, K. (2015). Work-life Balance Practices among Irish Hotel Employees and Implications for HRM Author. Dubline Institute of Technology, 13, 1-28.

Grego-planer, D. (2019). The Relationship between Organizational Commitment and Organizational Citizenship Behaviors in the Public and Private Sectors. 1-20.

Jang, J., \& Kandampully, J. (2018). Reducing Employee Turnover Intention Through Servant Leadership in the Restaurant Context: A Mediation Study of Affective Organizational Commitment. International Journal of Hospitality and Tourism Administration, 19(2), 125-141. https://doi.org/10.1080/15256480.2017.1305310

Jones, P., \& Comfort, D. (2019). Sustainable Development Goals and the World's Leading Hotel Groups. Athens Journal of Tourism, 6(1), 1-14. https://doi.org/10.30958/ajt.6-1-1

Keskes, I. (2014). Relationship between leadership styles and dimensions of employee organizational commitment: A critical review and discussion of future directions. Intangible Capital. https://doi.org/10.3926/ic.476

Kindy, A. M. Z. Al, Shah, I. M., \& Jusoh, A. (2016). Consideration and Methodological Approaches in Studying Transformational leadership Impact on Work Performance Behaviors. International Journal of Advanced Research (IJAR), 4(1), 889-907. http://www.journalijar.com/uploads/755_IJAR-8565.pdf

Krog, C. L., \& Govender, K. (2015). The relationship between servant leadership and employee empowerment, commitment, trust and innovative behaviour: A project management 
perspective. SA Journal of Human Resource Management, 13(1), 1-12. https://doi.org/10.4102/sajhrm.v13i1.712

Lo, M. C., Ramayah, T., Min, H. W., \& Songan, P. (2010). The relationship between leadership styles and organizational commitment in Malaysia: Role of leader-member exchange. Asia Pacific Business Review, 16(1-2), 79-103. https://doi.org/10.1080/13602380903355676

Ma, E., \& Qu, H. (2011). Social exchanges as motivators of hotel employees' organizational citizenship behavior: The proposition and application of a new three-dimensional framework. International Journal of Hospitality Management, 30(3), 680-688. https://doi.org/10.1016/j.ijhm.2010.12.003

Meyer, J. P., \& Allen, N. J. (1984). Testing the "side-bet theory" of organizational commitment: Some methodological considerations. Journal of Applied Psychology, 69(3), 372-378. https://doi.org/10.1037/0021-9010.69.3.372

Meyer, J. P., Allen, N. J., \& Smith, C. A. (1993). Commitment to organizations and occupations: Extension and test of a three-component conceptualization. Journal of Applied Psychology, 78(4), 538-551. https://doi.org/10.1037//0021-9010.78.4.538

Naiemaha, S., Sultan, A. A., Azizirb, A., Ruslan, I., \& Ruswahida. (2019). The relationship between organizational commitment, employee engagement, job satisfaction and turnover intention: Evidences in the malaysian hospitality sector. International Journal of Advanced Science and Technology, 28(13), 473-482.

Northouse, P. (2012). Leadership: Theory and Practice (5th edition). In Journal of Educational Administration (Vol. 50, Issue 3). SAGE Publications, Inc.

https://doi.org/10.1108/09578231211232022

Ozdemir, S. (2017). the Impact of Leadership Styles on Organizational Commitment and Turnover. 4th International Multidisciplinary Scientific Conference on Social Sciences and Arts Sgem2017, Modern Science, 4(April), 55-62.

https://doi.org/10.5593/sgemsocial2017/15/s05.125

Pelenk, S. E. (2020). The Mediation Effect of Leader Support in the Effect of Organizational Commitment on Job Satisfaction : A Research in the Turkish Textile Business. 9, 227-242.

Piong, C. (2016). Servant Leadership, Organizational Commitment, and Perceived Organizational Support in the Restaurant Industry. ProQuest Dissertations and Theses, Walden University.Retrieved from : https://scholarworks.waldenu.edu/dissertations

Richardson, S. (2010). Generation Y's perceptions and attitudes towards a career in tourism and hospitality. Journal of Human Resources in Hospitality and Tourism, 9(2), 179-199. https://doi.org/10.1080/15332840903383855

Saeed, M., Siddiq, B., Juliana, E., Ali, M., \& Ariffin, H. (2018). Leadership Styles And Employee Job Satisfaction In The Hotel Industry In Kuala Lumpur. 5(11), 89-106.

Tan, J. X., Cham, T. H., Zawawi, D., \& Aziz, Y. A. (2019). Antecedents of organizational citizenship behavior and the mediating effect of organization commitment in the hotel industry. Asian Journal of Business Research, 9(2), 121-139.

https://doi.org/10.14707/ajbr.190064

TOURISM MALAYSIA. (2018). Malaysia Tourism Key Performance Indicators. Retrieved from: mytourismdata.tourism.gov.my

Yahaya, R., \& Ebrahim, F. (2016). Leadership styles and organizational commitment: literature review. Journal of Management Development. https://doi.org/10.1108/JMD-01-20150004

Yeh, C. M. (2019). The relationship between tourism involvement, organizational 
commitment and organizational citizenship behaviors in the hotel industry. Tourism and Hospitality Management, 25(1), 75-93. https://doi.org/10.20867/thm.25.1.10

Zainuddin, N. S., Azim, A. M. M., \& Miskan, N. (2019). Pengaruh Keadilan Organisasi Terhadap Komitmen Afektif Dalam Kalangan Kakitangan Hotel Di Melaka: Modal Psikologi Sebagai Pengantara. Journal Of Business Innovation, 4(1), 76-89.

http://www.kuim.edu.my/journal/index.php/JBI/article/view/444

Zhao, S. (2019). Leadership Style and Followers' Organizational Commitment in the Chinese Context, Doctoral dissertation, University of Maryland University College. 